
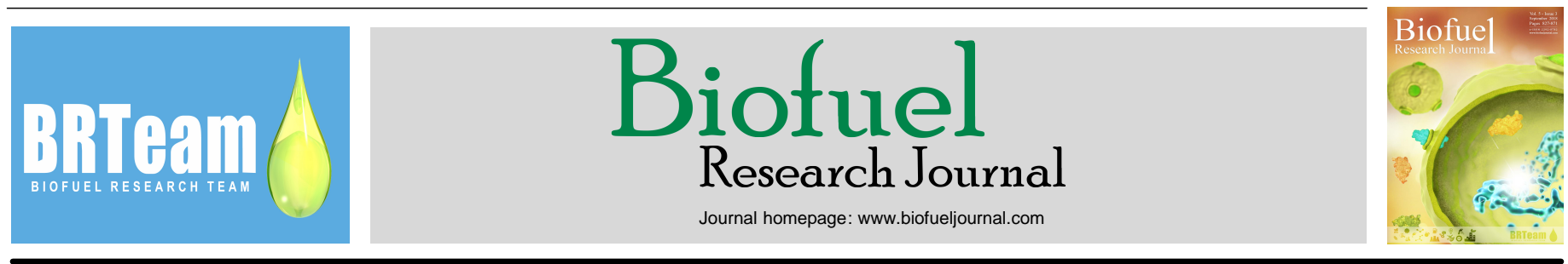

Original Research Paper

\title{
Experimental investigation of the combustion characteristics of Mahua oil biodiesel-diesel blend using a DI diesel engine modified with EGR and nozzle hole orifice diameter
}

\author{
M. Vijay Kumar,*, A. Veeresh Babu², P. Ravi $\operatorname{Kumar}^{2}$, S. Sudhakara Reddy ${ }^{1}$ \\ ${ }^{I}$ Department of mechanical engineering, Malla Reddy Engineering College, Hyderabad, Telangana, 500100, India. \\ ${ }^{2}$ Department of mechanical engineering, National Institute of Technology Warangal, Warangal, Telangana, 506004, India.
}

\section{HIGHLIGHTS}

$>$ Engine modification through reducing NHD improved combustion characteristics but deteriorated $\mathrm{NO}_{\mathrm{x}}$ emissions.

$>$ Application of partially-cooled EGR could compensate for the adverse impacts of engine modification on $\mathrm{NO}_{\mathrm{x}}$ emissions.

$>$ The EGR rate of $10 \%$ was found promising in substatially reducing $\mathrm{NO}_{\mathrm{x}}$ emissions at all loads. $>$ High EGR rates esp. at higher loads, adversely affected the performance and emission characteristics of the modified.

\section{GRAPHICAL ABSTRACT}

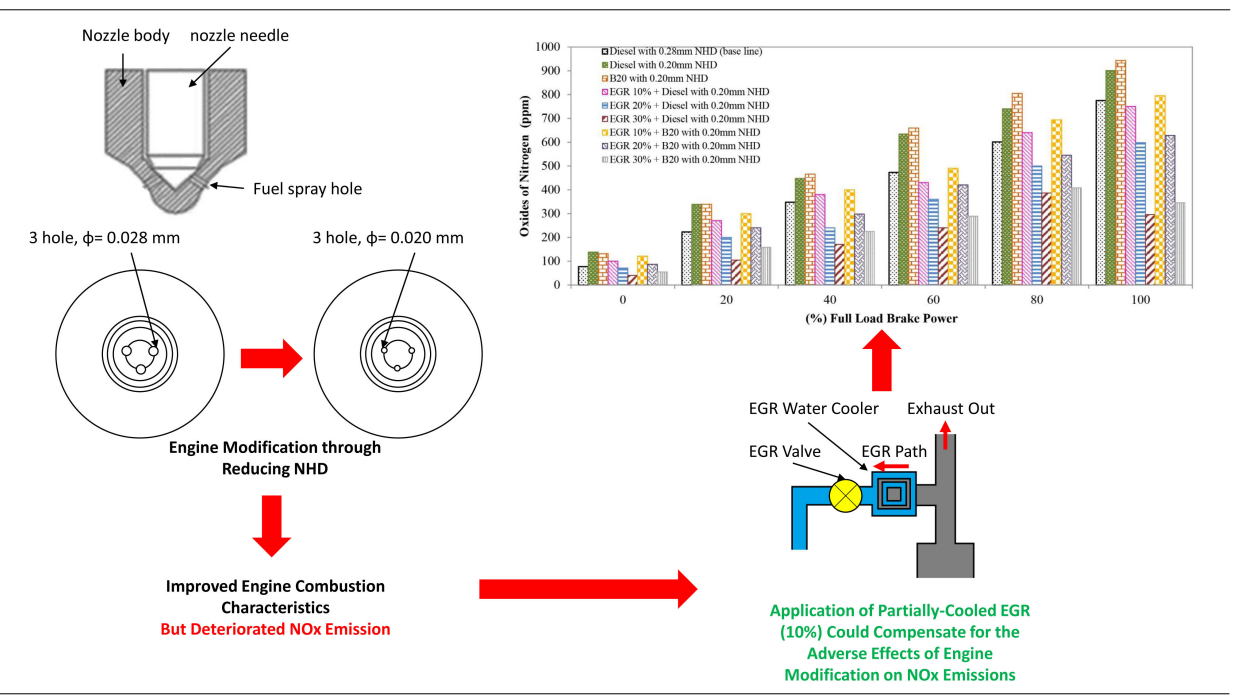

\section{ARTICLE INFO}

\section{Article history:}

Received 12 June 2018

Received in revised form 10 August 2018

Accepted 12 August 2018

Available online 1 September 2018

\section{Keywords:}

Diesel engine modification

Injector nozzle hole diameter

Biodiesel

Combustion characteristics

EGR

$\mathrm{NO}_{\mathrm{x}}$ reduction

\begin{abstract}
Engine modification through reducing nozzle hole diameter (NHD) (i.e., from the base value of 0.28 to the modified value of $0.20 \mathrm{~mm}$ ) has been shown as an effective strategy in improving engine performance, combustion, and emission parameters. However, it has also led to substantial increases in $\mathrm{NO}_{\mathrm{x}}$ emission as a major shortcoming. In light of that, the present study was aimed at overcoming this challenge through the application of a partially-cooled exhaust gas recirculation (EGR) system. More specifically, Mahua oil biodiesel-diesel blend (B20) and neat diesel were tested on a modified single cylinder diesel engine under five different engine loads (i.e., 2.46, 4.92, 7.38, 9.84, and $12.3 \mathrm{~kg}$ ) and in the presence of varying EGR rates (i.e., 10, 20, and $30 \%$ ). The results obtained revealed that the performance, combustion, and emission characteristics of the modified engine (3-hole nozzle with an orifice diameter of $0.20 \mathrm{~mm}$ ) were improved for both neat diesel and $\mathrm{B} 20$ except in the case of $\mathrm{NO}_{\mathrm{x}}$, in comparison with those of the conventional diesel engine (3-hole nozzle with an orifice diameter of $0.28 \mathrm{~mm}$ ). The considerable increases in $\mathrm{NO}_{\mathrm{x}}$ emissions caused by the smaller orifice NHD could be successfully compensated for through the implementation of the partially-cooled EGR. Overall and based on the findings of the present study, the proposed engine modification in the presence of partially-cooled EGR rate of $10 \%$ could be recommended as efficient combustion conditions for $20 \%$ blend of Mahua oil biodiesel and diesel. However, further increments in the EGR rate and in particular at higher loads, adversely affected the performance and emission characteristics of the modified engine due to the recirculation of high amounts of unburnt soot, $\mathrm{CO}_{2}, \mathrm{H}_{2} \mathrm{O}$, as well as of $\mathrm{O}_{2}$ deficiency.
\end{abstract}

(C) 2018 BRTeam. All rights reserved.

E-mail address: vijaykumar.iitm37@ gmail.com

Please cite this article as: Vijay Kumar M., Veeresh Babu A., Ravi Kumar P., Sudhakara Reddy S. Experimental investigation on the diesel and MME blend with DI diesel engine modified with EGR and nozzle hole orifice diameter. Biofuel Research Journal 19 (2018) 863-871. DOI: 10.18331/BRJ2018.5.3.6 


\begin{tabular}{|ll|}
\hline Abbreviations & \\
BP & Brake Power \\
BSFC & Brake Specific Fuel Consumption \\
BTE & Brake Thermal Efficiency \\
bTDC & before Top Dead Center \\
CI & Compression Ignition \\
CO & Carbon Monoxide \\
CO & Carbon Dioxide \\
CR & Compression Ratio \\
EGR & Exhaust Gas Recirculation \\
DI & Direct Injection \\
HC & Hydrocarbon \\
HRR & Heat Release Rate \\
ID & Ignition Delay \\
IP & Ignition Pressure \\
IT & Injection Timing \\
NHD & Nozzle Hole Diameter \\
NOx & Oxides of Nitrogen \\
PM & Particulate Matter \\
SOC & Start of Combustion \\
SCR & Selective Catalytic Reduction \\
\hline
\end{tabular}

\section{Introduction}

Growing interests in achieving higher power with better fuel economy at a lesser maintenance cost have been the driving force behind the increasing number of compression ignition $(\mathrm{CI})$ engine vehicles. In line with that, engine manufacturers constantly strive to further develop the CI engine technology to more efficiently meet the above-mentioned objectives. It should be mentioned that among these objectives, reducing exhaust gas emissions in order to meet the increasingly stringent emissions standards/policies is of utmost importance. Therefore, different engine modifications, methods/approaches for exhaust gas after-treatment, and strategies leading to more optimized combustion such as the application of more environmentally-friendly fuels/fuel additives have attracted a great deal of attention (Hussain et al., 2012; Vijay Kumar et al., 2018a). A number of these solutions are discussed herein.

\subsection{Biodiesel}

Biodiesel is defined as the mono-alkyl esters of long chain fatty acids resulting from vegetable oils or animal fats (Venkanna and Reddy, 2009; Vijay Kumar et al., 2017a). The critical properties of biodiesel, such as being nontoxic, high cetane number, oxygen content, absence of sulfur, high inherent lubricity, and being biodegradable, make this alternative fuel an ideal replacement for mineral diesel. Biodiesel can be used in neat form or with diesel at different blending ratios with no or little engine modification. Nevertheless, engine manufacturers recommend biodiesel blending ratios of up to $20 \%$ for the existing diesel engines (Mo et al., 2016).

In spite of the above-mentioned advantages, biodiesel is associated with a number of disadvantages as well including lower volumetric energy capacity, lower oxidative stability, inferior cold flow properties, higher kinematic viscosity, and higher $\mathrm{NO}_{\mathrm{x}}$ emissions (Can et al., 2016). Moreover, the widespread use of edible vegetable oil for biodiesel production has sparked much concern over the growing food vs. fuel competition over food resources/water/land. Additionally, edible oils could be more costly to use as biodiesel feedstock jeopardizing the economic viability of the biodiesel production process. Hence, the application of non-edible oil crops such as Sterculia foetida, Soapnut, Jatropha, Mahua, Pongamia, Polanga, Neem, etc. has been offered to overcome these challenges (Sahoo et al., 2007; Kumar and Sharma, 2011). Table 1 tabulates the estimated oil yields of mahor non-edible oil crops used as biodiesel feedstock.

While the application of many of the non-edible oil crops as biodiesel feedstock is still being assessed, these crops in general offer the following advantages (Atabani et al., 2013):

- The cultivation of non-edible oil feedstock requires non-agricultural and marginal land with little fertilizer and irrigation requirements.
- $\quad$ Non-edible oil crops can also be grown in semi-arid zones with an annual precipitation of around $200 \mathrm{~mm}$.

- $\quad$ Following oil extraction, the seed cakes can be used as fertilizer for soil improvement and/or biopesticide (Vijay Kumar et al., 2018b).

Table 1.

Estimated oil yields of non-edible oil crops used for biodiesel production.

\begin{tabular}{|c|c|c|c|}
\hline Type of oil & $\begin{array}{l}\text { Oil yield } \\
\text { (T/ha) }\end{array}$ & $\begin{array}{l}\text { Oil yield per } \\
\text { seed (wt. \%) }\end{array}$ & References \\
\hline Mahua & 3.600 & $44.43-61.5$ & $\begin{array}{l}\text { Jena et al. (2010); Kumar and Sharma } \\
\text { (2011); Soo-Young (2011) }\end{array}$ \\
\hline Polanga & 4.680 & 50 & Azam et al. (2005); Sahoo et al. (2006) \\
\hline Jatropha & $1.900-2.250$ & $35-40$ & $\begin{array}{l}\text { Achten et al. (2008); Gui et al. (2008); } \\
\text { Pinzi et al. (2009); Singh and Singh } \\
\text { (2010); Koh and Ghazi (2011); } \\
\text { Silitonga et al. (2011) }\end{array}$ \\
\hline Neem & 2.670 & $20-30$ & $\begin{array}{l}\text { Azam et al. (2005); Nabi et al. (2006); } \\
\text { Kumar and Sharma (2011); Sharma et } \\
\text { al. (2011); Soo-Young (2011) }\end{array}$ \\
\hline Pongamia & $0.225-2.250$ & $30-40$ & $\begin{array}{l}\text { Azam et al. (2005); Karmee and } \\
\text { Chadha (2005); Gui et al. (2008); Naik } \\
\text { et al. (2008); Pinzi et al. (2009); Singh } \\
\text { and Singh (2010); Soo-Young (2011) }\end{array}$ \\
\hline Rubber seed & $0.040-0.120$ & $40-50$ & $\begin{array}{l}\text { Ramadan and Morsel (2003); } \\
\text { Ramadhas et al. (2005a); Ramadhas et } \\
\text { al. (2005b); Kumar and Sharma (2011); } \\
\text { Soo-Young (2011) }\end{array}$ \\
\hline Castor & 1.188 & $45-50$ & $\begin{array}{l}\text { Koutroubas et al. (1999); Saka (2005); } \\
\text { Soo-Young (2011) }\end{array}$ \\
\hline
\end{tabular}

\subsection{Biodiesel application without engine modifications}

Many research studies have recommended the application of biodiesels produced from different oil feedstock without requiring any engine modifications. For instance, Polanga oil methyl ester (POME) and its blends were combusted at varying loads by Sahoo et al. (2007). The authors claimed more favorable engine performance parameters such as brake thermal efficiency (BTE) and brake specific energy consumption (BSEC) using POME blends compared with neat diesel. They also argued that smoke opacity and hydrocarbon (HC) emissions were decreased in response to POME inclusion while NOx was increased owing to the oxygen content of biodiesel (Sahoo et al., 2007). Similar results were reported by Mofijur et al. (2013) who investigated two blending ration of biodiesel into diesel, i.e., B10 and B20. They indicated that the average BSFC values obtained for B10 $(278.46 \mathrm{~g} / \mathrm{kWh})$ and B20 $(281.9 \mathrm{~g} / \mathrm{kWh})$ were higher than that of neat diesel $(273.5 \mathrm{~g} / \mathrm{kWh})$.

Whereas, compared to neat diesel, B10 and B20 led to lower CO (16\% and $25 \%$, respectively) and $\mathrm{HC}(3.84 \%$ and $10.25 \%$, respectively) emissions, but a slightly higher NOx emissions (3\% and 6\%, respectively (Mofijur et al., 2013). In a different study, Karanja biodiesel and its blends were found compatible with the existing diesel engines (Chauhan et al, 2013). From the unfavorable combustion characteristics point of view, it was found that compared with neat diesel, Karanja biodiesel blends led to 3-5\% less BTE, lower in-cylinder pressure, and lower heat release rate (HRR), but increased $\mathrm{NO}_{\mathrm{x}}$ emissions (Chauhan et al., 2013). Raheman and Phadatare (2004) as well as Agarwal and Dhar (2013) also studied the combustion characteristics of Karanja biodiesel and claimed reductions in emissions, i.e., $\mathrm{CO}, \mathrm{HC}$, and smoke.

These findings were in line with those of the other investigations on biodiesel produced from other oil feedstocks such Pongamia Pinnato biodiesel (Sureshkumar et al., 2008), Mahua oil biodiesel (Raheman and Ghadge, 2007; Vijay Kumar et al., 2017b), mango seed oil biodiesel (Vijayaraj and Sathiyagnanam, 2016), palm and Jatropha biodiesel (Rahman et al., 2014), etc. Overall, these studies are unanimous in concluding that biodiesel can be used by up to $20 \%$ (i.e., B20) in the existing diesel engines without modifications and that it could lead to reduced emissions (except $\mathrm{NO}_{\mathrm{x}}$ ). 


\subsection{Biodiesel application along engine modifications}

Some research works have been focused on investigating the effects of various engine modifications, e.g., compression ratio (CR), injection timing (IT), pressure opening, etc. on diesel engines powered by biodiesel-diesel blends. For instance, Ganapathy et al. (2011) claimed reductions in BSFC as well as $\mathrm{HC}, \mathrm{CO}$, and smoke emissions by applying variations in injection timing when using Jatropha biodiesel. They also argued that HRR, pressure, and BTE could be increased while $\mathrm{NO}_{\mathrm{x}}$ emissions could be reduced through such variations. In a different study, Gnanase Karan et al. (2016) studied the combustion characteristics of a diesel engine running on fish oil biodiesel and its blends at different injection timings, i.e., $21^{\circ}$ bTDC, $24^{\circ}$ bTDC, and $27^{\circ}$ bTDC. They reported shorter ignition delays (ID) and lower HRRs for biodiesel blends. They also argued that through the retardation of IT, a number of emission and combustion parameters including $\mathrm{NO}_{\mathrm{x}}, \mathrm{HC}, \mathrm{CO}$, peak pressure, ID, combustion duration, and HRR were decreased while advancement in IT led to opposite results (Gnanase Karan et al., 2016).

Variations in ignition pressure (IP) has also taken into account by a number of investigations. For instance, Channapattana et al. (2015) and Shehata et al. (2015) studied the effects of varying IPs on the combustion characteristics of Honne biodiesel and corn/soybean biodiesel blends, respectively. These authors concluded increases in $\mathrm{NO}_{\mathrm{x}}$ emissions and decreases in $\mathrm{HC}, \mathrm{CO}$, and smoke opacity in response to increasing IP. In a recent investigation, Dubey and Gupta (2018) took into consideration the effects of increasing compression ratio (CR) (i.e., 15.5:1, 17:1, 18.5:1, and 20:1) on the performance and emissions profile of a dual biofuel (Jatropha biodiesel and turpentine oil). They claimed that at the CR of 20:1, the investigated biofuel led to the most favorable results, i.e., increased BTE by $2.17 \%$ as well as decreased $\mathrm{CO}, \mathrm{HC}, \mathrm{NO}_{\mathrm{x}}$ emissions, and smoke opacity by $13.04 \%, 17.5 \%, 4.21 \%$, and $30.8 \%$, respectively (Dubey and Gupta, 2018). Lower HC and CO emissions were also recorded by Sivaramakrishnan (2018) through optimizing IP at 200 bar and CR at $18: 1$ when combusting a $25 \%$ blend of Karanja biodiesel. Similar results were also reported by Jindal et al. (2010) who claimed that higher CRs and higher IPs improved the engine performance of a diesel engine running on Jatropha biodiesel.

\subsection{Biodiesel application with after-treatment technologies}

Efforts to reduce the $\mathrm{NO}_{\mathrm{x}}$ emissions associated with the application of biodiesel have been intensified over the last decade. In line with that, selective catalytic reduction (SCR) and exhaust gas recirculation (EGR) have been offered as proven technologies for reducing $\mathrm{NO}_{\mathrm{x}}$ emissions. For instance, in a study, Hussain et al. (2012) investigated the effect of EGR (10\%, 15\%, $20 \%$ and $25 \%$ ) on a 3-cylinder, constant speed, and air-cooled CI diesel engine and concluded that at lower loads, higher rates of EGR could be applied without negatively affecting the fuel economy and efficiency, while leading to reduced $\mathrm{NO}_{\mathrm{x}}$. Duraisamy et al. (2011) combusted Jatropha biodiesel using EGR and argued that EGR of $15 \%$ was optimal in terms performance improvement and reduction in $\mathrm{NO}_{\mathrm{x}}$ emission. Similar findings verifying the favorable impacts of EGR have also been reported by other studies (Kusaka et al., 2000; Rajan and Senthilkumar, 2009; Bani et al., 2010; Fontana and Galloni, 2010; Mani et al., 2010). These improvements in response to EGR application could be explained by the resultant high intake temperature, which improves flame propagation in the combustion chamber (Sasaki et al., 1998).

In our recently published report, the combination of Mahua oil biodiesel blend (B20) application with engine modification, i.e., the implementation of smaller orifice nozzle hole diameter (NHD), was shown to lead to improved combustion characteristics (Vijay Kumar et al., 2018b). However, the combined strategy also led to $\mathrm{NO}_{\mathrm{x}}$ augmentation as its only drawback observed. These outcomes could be ascribed to the more efficient atomization of the fuel particles triggered by the smaller orifice NHD and the consequently more effective fuel combustion taking place in the combustion chamber on one hand and the high oxygen content of the fuel blend on the other hand (Vijay Kumar et al., 2018b). In light of that, the present study was set to overcome the shortcoming of the investigated strategy or in better words, to reduce $\mathrm{NO}_{\mathrm{x}}$ emissions by employing EGR while using Mahua oil biodiesel blend and small orifice NHD.

\section{Experimental Procedure}

\subsection{Biodiesel preparation}

Biodiesel was produced as described in our previous report (Vijay Kumar et al., 2018b). Briefly, inedible Mahua oil was transesterified through a two-step procedure. This strategy was employed owing to the high free fatty acids (FFA) of this oil feedstock, i.e., $21 \%$. In the first step, the FFA content was reduced through mixing $0.35 \mathrm{v} / \mathrm{v}$ of methanol and $1 \%$ $\mathrm{v} / \mathrm{v}$ of concentrated $\mathrm{H}_{2} \mathrm{SO}_{4}$ with the pre-heated Mahua oil at $60{ }^{\circ} \mathrm{C}$ for $1 \mathrm{~h}$. Subsequently, the resultant oil was transesterified by using $0.25 \mathrm{v} / \mathrm{v}$ of methanol and $0.7 \% \mathrm{w} / \mathrm{v}$ of $\mathrm{KOH}$ at $60{ }^{\circ} \mathrm{C}$ for $1 \mathrm{~h}$. Following glycerin decantation, crude biodiesel was washed with $50{ }^{\circ} \mathrm{C}$ distilled water three times. Finally, anhydrous $\mathrm{CaCl}_{2}$ was added to the resultant product, heated gently at $50{ }^{\circ} \mathrm{C}$ while shaken vigorously. Dry purified Mahua oil biodiesel was obtained after $\mathrm{CaCl}_{2}$ separation and blended with diesel to obtain B20 fuel.

Fuel properties of diesel, Mahua oil biodiesel and its 20\% blend with diesel (B20) are presented and compared in Table 2. The chemical compositions of diesel and Mahua oil biodiesel are tabulated in Table 3.

Table 2.

Fuel properties of neat diesel, Mahua oil biodiesel as well as its $20 \%$ blend with diesel (B20).*

\begin{tabular}{lllll}
\hline Property & Unit & Diesel & $\begin{array}{l}\text { Mahua oil } \\
\text { biodiesel }\end{array}$ & B20 \\
\hline Colour & - & Light brown & Slight brown yellow & Light brown \\
Density at $35{ }^{\circ} \mathrm{C}$ & $\mathrm{Kg} / \mathrm{m}^{3}$ & 819 & 867 & 831 \\
Viscosity at $40{ }^{\circ} \mathrm{C}$ & $\mathrm{cSt}$ & 2.89 & 4.86 & 3.36 \\
Calorific value & $\mathrm{kJ} / \mathrm{kg}$ & 44296 & 38513 & 43761 \\
Fire point & ${ }^{\circ} \mathrm{C}$ & 52 & 140 & $\mathrm{ND}^{1}$ \\
Flash point & ${ }^{\circ} \mathrm{C}$ & 48 & 108 & $\mathrm{ND}$ \\
Pour point & ${ }^{\circ} \mathrm{C}$ & -5 & 10.2 & $\mathrm{ND}$ \\
Cloud point & ${ }^{\circ} \mathrm{C}$ & -10 & 14.5 & $\mathrm{ND}$ \\
Boiling point & ${ }^{\circ} \mathrm{C}$ & $282-338$ & 320 & $\mathrm{ND}$ \\
Cetane number & - & 49 & 52 & $\mathrm{ND}$ \\
\hline${ }^{1} \mathrm{ND}=$ Not determined & & &
\end{tabular}

* Source: Vijay Kumar et al. (2018b). With permission from Elsevier. Copyright@ 2018.

Table 3.

Comparison of chemical composition of diesel and Mahua oil biodiesel.*

\begin{tabular}{lll}
\hline Description & Diesel & Mahua oil biodiesel \\
\hline Carbon (\%) & 86.5 & 77.9 \\
\hline Oxygen $(\%)$ & 0 & 9.3 \\
\hline Nitrogen $(\%)$ & 0.18 & $<0.001$ \\
\hline Hydrogen $(\%)$ & 13.2 & 12.8 \\
\hline * Source: Vijay Kumar et al. (2018b). With permission from Elsevier. Copyright $\odot 2018$.
\end{tabular}

\subsection{Engine modifications with fuel injector nozzle and EGR}

First, the injection nozzle system of a diesel engine was modified to smaller orifice diameter in order to improve the performance and to reduce the harmful emissions as reported previously (Vijay Kumar et al., 2018b). Briefly, the reduction of NHD significantly affected the air-fuel mixture formation, atomization, and evaporation leading to improved BTE, BSFC, and HRR and reduced emissions (except $\mathrm{NO}_{\mathrm{x}}$ ) in the investigated $\mathrm{CI}$ engine. Subsequently, to overcome the challenge associated with the NHD modification, the coupling of a partially-cooled EGR system to the diesel engine was investigated.

Parametric details of the fuel injection systems used including the differences between the base and modified nozzle orifice diameters are presented in Table 4. For better understanding, cross-sectional views of the nozzle hole geometries are also shown in Figure 1. 
Table 4.

Parametric details of the fuel injection systems used.

\begin{tabular}{lllll}
\hline S. No. & Nozzle label & $\begin{array}{l}\text { No. of } \\
\text { holes }\end{array}$ & $\begin{array}{l}\text { Diameter of orifice } \\
\text { hole }\end{array}$ & $\begin{array}{l}\text { Standard nozzle } \\
\text { opening pressure }\end{array}$ \\
\hline 1 & NHD (base) & 3 & $0.28 \mathrm{~mm}$ & $210 \mathrm{bar}$ \\
2 & NHD (modified) & 3 & $0.20 \mathrm{~mm}$ & $210 \mathrm{bar}$ \\
\hline
\end{tabular}

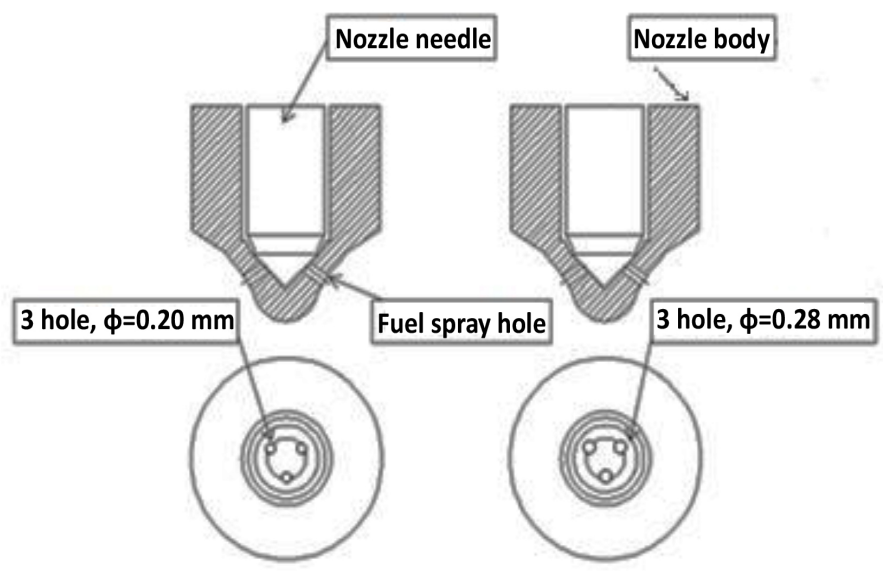

Fig.1. Cross section views of the nozzles with different orifice diameters. Source: Vijay Kumar et al. (2018b). With permission from Elsevier. Copyright@ 2018.
A computerized single cylinder diesel engine was employed to study the effects of reduced nozzle orifice diameter and EGR on the combustion (performance and emissions) characteristics of Mahua oil biodiesel blend. The specifications of the engine used is shown in Table 5. The engine was coupled to an eddy current dynamometer for loading the engine. For EGR, appropriate plumbing was done. To maintain the re-circulated exhaust gases partially cool, a water cooler was used while no insulation was considered on the pipeline to allow the escape of the heat. A control valve was installed to regulate the EGR percentage. An EGR mixture chamber was also provided to mix the exhaust gases with fresh air. The flow rate of the intake fresh air was monitored by an orifice meter. A schematic presentation of the engine setup coupled with the EGR system is shown in Figure 2. For EGR setupThe EGR (\%) was calculated according to the following equation (Eq. 1).

EGR rate $(\%)=\frac{Q_{\text {without EGR }}-Q_{\text {EGR }}}{Q_{\text {without EGR }}} \times 100$

Eq. 1

Where, $\mathrm{Q}_{\text {without EGR }}$ is the airflow rate without EGR, i.e., $26 \mathrm{~kg} / \mathrm{h}$ and $\mathrm{Q}_{\mathrm{EGR}}$ is the EGR flow rates investigated, i.e., $2.6 \mathrm{~kg} / \mathrm{h}, 5.2 \mathrm{~kg} / \mathrm{h}$, and $7.8 \mathrm{~kg} / \mathrm{h}$.

An AVL gas analyzer was used to measure $\mathrm{CO}, \mathrm{NO}_{\mathrm{x}}$, and $\mathrm{HC}$. The exhaust gas smoke opacity was measured by an AVL smoke opacity meter.

\subsection{Measuring devices; ranges, accuracies, and percentage uncertainties}

The ranges and accuracies of the measuring devices used in the present investigation are shown in Table 6 . While the percentage uncertainties of

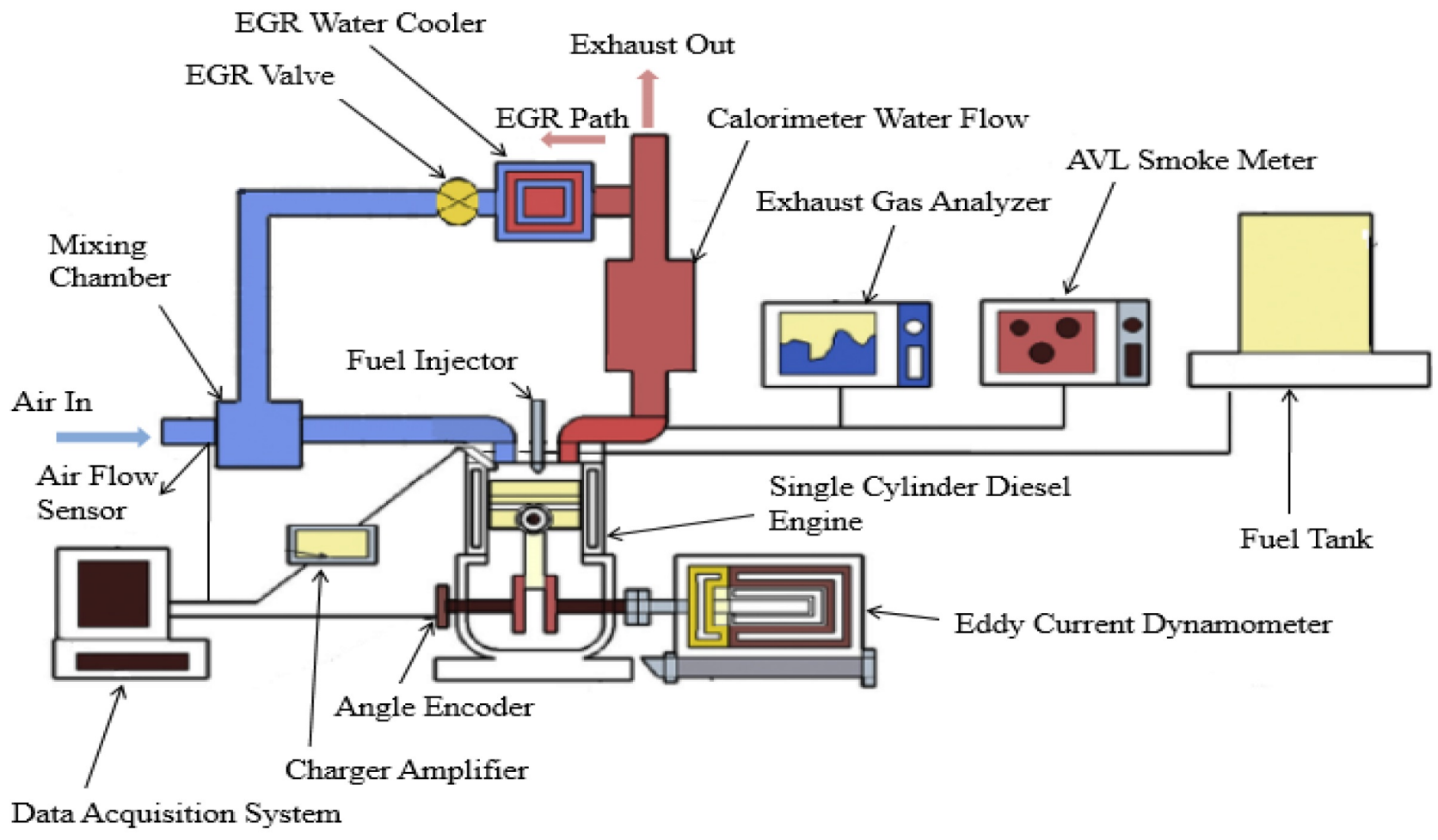

Fig.2. Schematic diagram of an experimental setup.

Please cite this article as: Vijay Kumar M., Veeresh Babu A., Ravi Kumar P., Sudhakara Reddy S. Experimental investigation on the diesel and MME blend with DI diesel engine modified with EGR and nozzle hole orifice diameter. Biofuel Research Journal 19 (2018) 863-871. DOI: 10.18331/BRJ2018.5.3.6 
various instruments and calculated parameters are tabulated in Tables 7 and 8 , respectively.

Table 5.

Specifications of the diesel engine used.

\begin{tabular}{ll}
\hline Name of the description & Details/value \\
\hline Make of mode & TV1-KIRLOSKAR \\
Engine type & $\begin{array}{l}\text { Four stroke, water cooled, single cylinder, DI } \\
\text { diesel engine }\end{array}$ \\
Loading device & Eddy current dynamometer \\
No. of cylinder & One \\
Rated power (kW) & 3.5 \\
Constant speed (rpm) & 1500 \\
Swept volume (cc) & 661 \\
Stroke length (mm) & 110 \\
Cylinder bore (mm) & 87.5 \\
Compression ratio & $17.5: 1$ \\
Connecting rod length (mm) & 234 \\
Injection timing $\left({ }^{\circ} \mathrm{CA}\right.$. bTDC) & 23 \\
Piston bowl & Hemispherical \\
Nozzle type & Multi-hole \\
Nozzle opening pressure (bar) & 210 \\
Number of nozzle hole & 3 \\
Modified nozzle spray hole diameter & 0.28 mm (base) and 0.20 mm (modified) \\
\hline
\end{tabular}

Table 6.

Accuracies and ranges of the measuring devices used in this study.

\begin{tabular}{lll}
\hline Quantity & Range & Accuracy \\
\hline AVL gas analyzer & NO: $0-5000 \mathrm{ppm}$ & $\pm 50 \mathrm{ppm}$ \\
& CO: $0-10 \%$ by vol. & $\pm 0.03 \%$ \\
& HC: $0-20000 \mathrm{ppm}$ & $\pm 10 \mathrm{ppm}$ \\
& $0-100 \%$ & $\pm 0.2 \%$ \\
AVL smoke meter & & \\
Pressure Sensor & & \\
Name: Dynamic pr. Transducer with & $(0-110 \mathrm{bars})$ & $\pm 0.05 \mathrm{bar}$ \\
$\quad$ built-in amplifier & & \\
Make: PCB Piezotronics, & & $\pm 0.1 \mathrm{psi}$ \\
Model: M111A22 & $0-5 \mathrm{psi}$ & $\pm 1^{\circ}$ \\
Fuel flow sensor & - & $\pm 10 \mathrm{rpm}$ \\
Crank angle encoder & $0-5000 \mathrm{rpm}$ & $\pm 1 \mathrm{~mm}$ of $\mathrm{H}_{2} \mathrm{O}$ \\
Speed measuring & $0-3.500 \mathrm{~mm}$ of $\mathrm{H}_{2} \mathrm{O}$ & $\pm 0.55 \mathrm{~A}, \pm 1 \mathrm{~V}$ \\
Air flow sensor & $0-20 \mathrm{~A}, 0-450 \mathrm{~V}$ & $\pm 1{ }^{\circ} \mathrm{C}$ \\
Alternator & $0-1000^{\circ} \mathrm{C}$ & \\
Thermocouples & & \\
\hline
\end{tabular}

Table 7.

Uncertainties of the instruments used in this study.

\begin{tabular}{ll}
\hline Instruments & Percentage uncertainties \\
\hline Pressure pick up & \pm 1.0 \\
Crank angle encoder & \pm 0.2 \\
Exhaust gas analyzer & \\
$\quad$ NO $_{\mathrm{x}}$ & \pm 0.2 \\
$\quad \mathrm{CO}$ & \pm 0.2 \\
$\quad \mathrm{HC}$ & \pm 0.2 \\
$\quad$ Smoke intensity & \pm 1.0 \\
Time $\quad$ & \pm 0.2 \\
Burette for fuel measurement & \pm 1.5 \\
Load indicator & \pm 0.5 \\
Speed & \pm 0.2 \\
Temperature & \pm 0.2 \\
\hline
\end{tabular}

Table 8.

Uncertainties of the calculate parameters.

\begin{tabular}{ll}
\hline Parameter & Percentage uncertainties \\
\hline Brake power & \pm 0.5 \\
Brake specific fuel consumption & \pm 1.5 \\
Brake thermal efficiency & \pm 1.0 \\
\hline
\end{tabular}

\subsection{Experimental testing procedure}

As mentioned earlier (see Section 2.2), the present work was aimed at overcoming the shortcoming observed in our previous investigation using Mahua oil biodiesel blend, i.e., increased $\mathrm{NO}_{\mathrm{x}}$ emissions in response to reduction in orifice NHD (Vijay Kumar et al., 2018b). More specifically, the two different fuels, i.e., neat diesel and B20 (20\% v of Mahua oil biodiesel $+80 \% \mathrm{v}$ of diesel) were used. Moreover, the base nozzle hole orifice diameter $(\varnothing=0.280 \mathrm{~mm})$ and modified nozzle hole orifice diameter $(\varnothing=0.20 \mathrm{~mm})$ were taken into account. Finally, the effect of EGR with three different rates (i.e., $10 \%, 20 \%$, and $30 \%$ ) was investigated. Baseline data were obtained by operating the engine at different loads with diesel fuel and base NHD and the experimental data were analyzed and compared with the baseline data.

\section{Results and Discussion}

\subsection{Engine performance analysis}

\subsubsection{Brake specific fuel consumption and brake thermal efficiency}

The variations in BSFC and BTE $v s$. full load BP for different combinations of nozzle orifice diameter, fuel type, and EGR rate are shown in Figure 3. As can be seen, there was a negative correlation between BSFC and BP. It should be noted that BSFC trend generally depends on density, viscosity, calorific value, and chemical composition of a given fuel. As revealed in our previous report, the smaller orifice NHD, i.e., $0.20 \mathrm{~mm}$, led to significantly less BSFC with both diesel and B20 because of the higher mixing rate achieved (Vijay Kumar et al., 2018b). In the present study, BSFC was reduced by implementing the EGR rate of $10 \%$ for both B20 and diesel fuel probably due to the returning of $\mathrm{HC}$ and that the partially-cooled EGR acted as a pre-heater of the intake mixture. Further increments of EGR rate, i.e., $20 \%$ and $30 \%$, resulted in increases in BSFC at both lower and higher loads (Fig. 3) due to the lack of sufficient $\mathrm{O}_{2}$ in the combustion chamber leading to incomplete combustion.

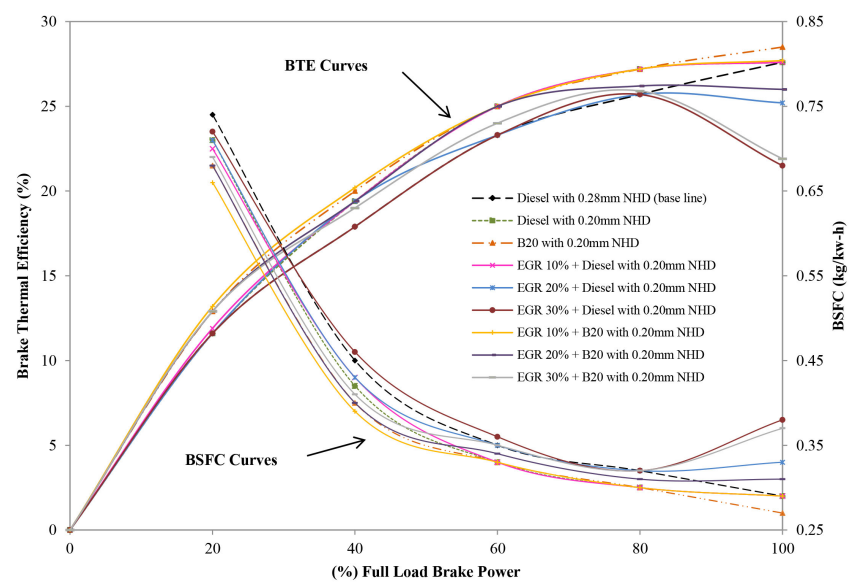

Fig.3. Variations in BSFC and BTE vs. full load BP for different combinations of nozzle orifice diameter, fuel type, and EGR rate.

There was a positive correlation between BTE and BP. When combusting neat diesel fuel, BTE was slightly increased by using the 0.20 
$\mathrm{mm}$ nozzle hole orifice diameter with. While in the case of B20 and the modified orifice diameter, the increases observed in BTE in response to increasing $\mathrm{BP}$ were more pronounced. This could be ascribed to the presence of $\mathrm{O}_{2}$ in biodiesel enhancing the combustion process and heat release. On the other hand, the small orifice NHD of $0.20 \mathrm{~mm}$ improved fuel vaporization and atomization. Using the modified nozzle orifice diameter and the partiallycooled EGR of $10 \%$, BTE was slightly increased for both B20 and diesel fuel. This could be explained by the re-burning of $\mathrm{HC}$ in the combustion chamber with EGR. At high loads, BTE is generally decreased due to introduction of a rich fuel mixture generating higher levels of $\mathrm{CO}_{2}$ and soot which could in turn lead to incomplete combustion. In line with that and as can also be seen in Figure 3, at higher loads and by suing higher EGR rates of $20 \%$ and $30 \%$, the re-burning of $\mathrm{HC}$ was much significant. Moreover, through the application high EGR rates, the in-cylinder temperature would be reduced and late HRR would occur leading to reduced peak pressure at different loads and consequently decreased BTE.

\subsection{Combustion parameters analysis}

\subsubsection{In-cylinder pressure}

The variations recorded in in-cylinder pressure against crank angle at full load condition for different combinations of nozzle orifice diameter, fuel type, and EGR rate are shown in Figure 4. The application of biodiesel blend and diesel fuel with smaller orifice diameter reduced the ID period because of the lower heat capacity as well as the increased $\mathrm{O}_{2}$ content and cetane number. The peak pressure was decreased with the application of EGR rates. It should be quoted that EGR is mainly composed of $\mathrm{CO}_{2}$, soot, and $\mathrm{H}_{2} \mathrm{O}$ resulting in reduced $\mathrm{O}_{2}$ concentration in the combustion chamber. The EGR function and the associated dilution and thermal effects led to slower chemical reactions and consequently, delayed start of combustion (SOC) and lengthier ID period. The latter intensified the premixed combustion phase.

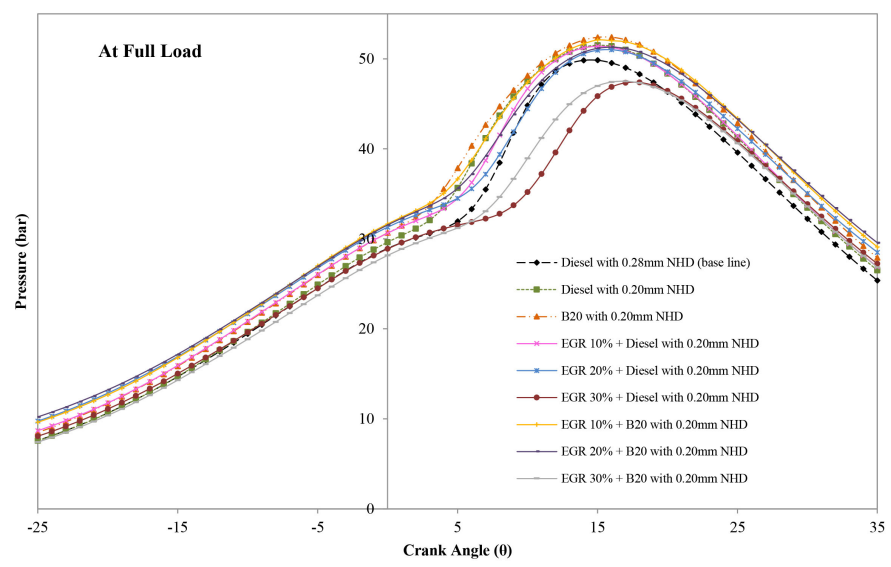

Fig.4. Variations in in-cylinder pressure against crank angle at full load for different combinations of nozzle orifice diameter, fuel type, and EGR rate.

\subsubsection{Maximum in-cylinder pressure}

The variations of maximum pressure at different percentages of full load BP for different combinations of nozzle orifice diameter, fuel type, and EGR rate are shown in Figure 5. The usage of biodiesel blend and diesel fuel with smaller orifice diameter reduced the ID period and led to increases in the pressure in the combustion chamber. As can be observed as BP was increased, the peak pressure increased as well. Comparing diesel and biodiesel blend at different EGR rates with the modified orifice diameter, it could be concluded that the application of EGR with B20 seemed to be more promising (Fig. 5) probably due to the $\mathrm{O}_{2}$ concentration of the biodiesel-containing blend (Lai et al., 2011).

\subsubsection{In-cylinder gas temperature}

The variations in the in-cylinder gas temperature with respect to different percentages of full load BP for different combinations of nozzle orifice

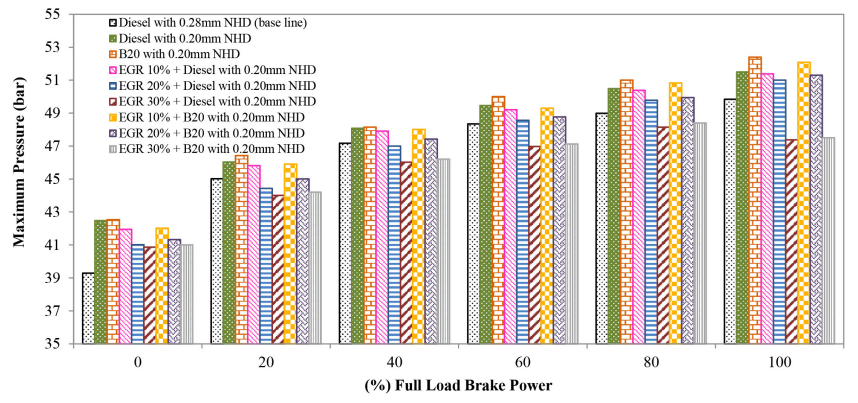

Fig.5. Variations of maximum pressure at different percentages of full load BP for different combinations of nozzle orifice diameter, fuel type, and EGR rate.

diameter, fuel type, and EGR rate are shown in Figure 6. The in-cylinder gas temperature trend indicated that as the BP was increased, the gas temperature rose as well. Furthermore, the temperature was increased by reducing the orifice diameter using B20. This was ascribed to both the oxygen content of biodiesel (Lai et al., 2011) and the more efficient spraying of the fuel leading to more favorable atomization of the fuel particles and consequently more complete combustion process.

When the diesel engine was operated with partially-cooled EGR, the temperature was reduced under all operating conditions. More specifically, there was a negative correlation between the in-cylinder gas temperature and the EGR rates. This could be explained by the decreasing $\mathrm{O}_{2}$ availability and increasing specific heat of intake mixture in response to increasing EGR rates.

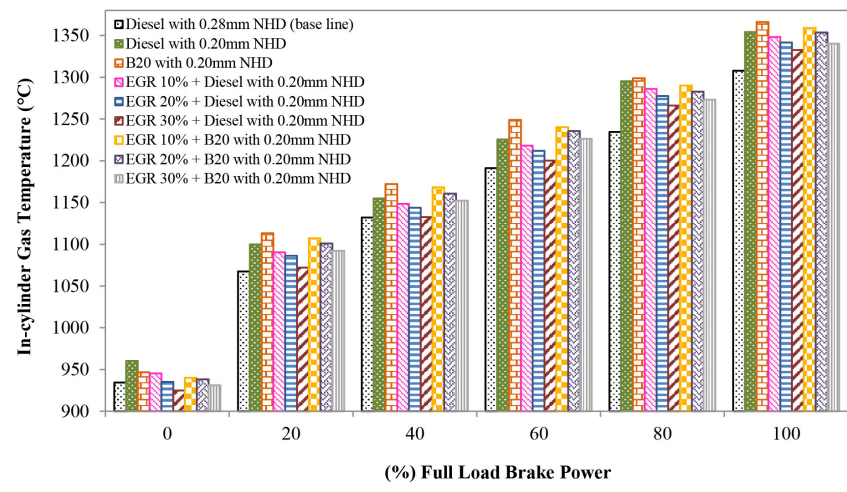

Fig.6. Variations in the in-cylinder gas temperature with respect to different percentages of full load BP for different combinations of nozzle orifice diameter, fuel type, and EGR rate.

\subsubsection{Heat release rate}

The variations in HRR against crank angle at full load condition for different combinations of nozzle orifice diameter, fuel type, and EGR rate are shown in Figure 7. HRR is mainly dependent on ID, heating value of fuel, and air-fuel mixing. In fact, HRR is used to identify the differences in the combustion rates of fuels, the fraction of fuel burnt in the premixed process, and the SOC. The HRR for B20 with $0.20 \mathrm{~mm}$ nozzle orifice diameter was found to be lower with the early SOC (Fig. 7).

As the EGR rate was increased for diesel and B20, the HRR was increased as well due to the late $\mathrm{SOC}$ which was caused by the recirculation of $\mathrm{CO}_{2}$, soot, and $\mathrm{H}_{2} \mathrm{O}$. Overall, the EGR rate of $10 \%$ with $\mathrm{B} 20$ seemed to be more promising than the other EGR rates (Fig. 7). 


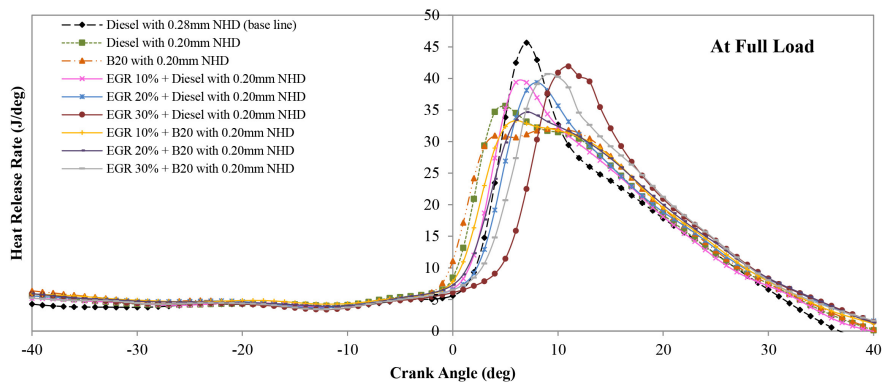

Fig.7. Variations in HRR against crank angle at full load condition for different combinations of nozzle orifice diameter, fuel type, and EGR rate.

\subsection{Engine emissions analysis}

\subsubsection{Carbon monoxide}

The variations in $\mathrm{CO}$ emission at different percentages of full load BP for different combinations of nozzle orifice diameter, fuel type, and EGR rate are shown in Figure 8. CO is mainly formed due to incomplete combustion. This takes place when there is not enough $\mathrm{O}_{2}$ present to react with fuel. By using the modified $0.20 \mathrm{~mm}$ nozzle orifice diameter with $\mathrm{B} 20$, CO emissions were reduced due to the better atomization of the fuel. Through the application of the partially-cooled EGR, the CO emissions were increased. More specifically, these increments in $\mathrm{CO}$ emissions were proportional with increasing EGR rates. The reason behind increased $\mathrm{CO}$ emissions was the low in-cylinder temperature and reduced peak pressure mainly caused by the recirculation of high amounts of unburnt soot, $\mathrm{CO}_{2}, \mathrm{H}_{2} \mathrm{O}$, as well as $\mathrm{O}_{2}$ deficiency (Duraisamy et al., 2011).

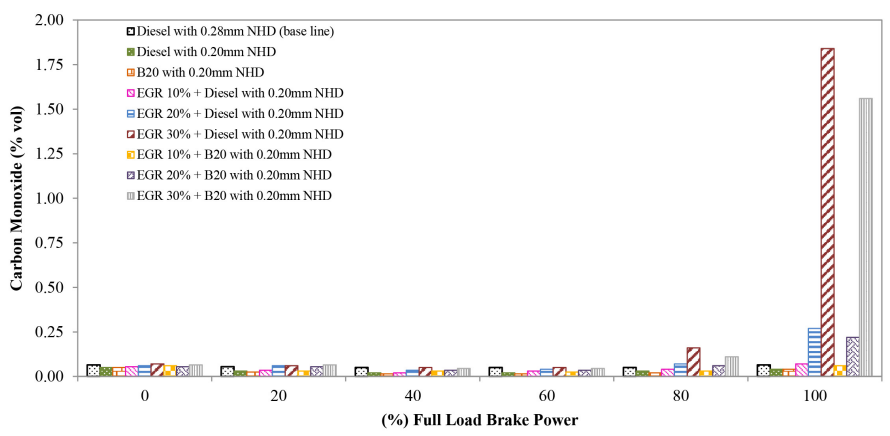

Fig.8. variations in CO emission at different percentages of full load BP for different combinations of nozzle orifice diameter, fuel type, and EGR rate.

\subsubsection{Hydrocarbon}

The variations of unburned $\mathrm{HC}$ at different percentages of full load BP for different combinations of nozzle orifice diameter, fuel type, and EGR rate are shown in Figure 9. HC emissions originate from the presence of too many fuel particles left unburned in the combustion chamber due to incomplete combustion. It also appears in the inner layers during the diffusion flame where there is more fuel than air. As presented, $\mathrm{HC}$ emissions were substantially reduced by using the modified orifice diameter with both diesel and B20 fuel (Fig. 9). This was mainly ascribed to the more atomization of the fuel and proper air-fuel mixing in the combustion chamber. When EGR was used in combination with the modified orifice diameter and both B20 and diesel, increases in $\mathrm{HC}$ were recorded. At high loads and by suing the EGR rate of $30 \%$, HC emissions were drastically increased due to the reductions in incylinder temperature and pressure reduction. This was because of higher deficiency of $\mathrm{O}_{2}$ leading the rich fuel mixture inside the combustion chamber
(Fontana and Galloni, 2010). In another word, such heterogeneous mixtures do not combust entirely and result in increased $\mathrm{HC}$ emissions at higher loads.

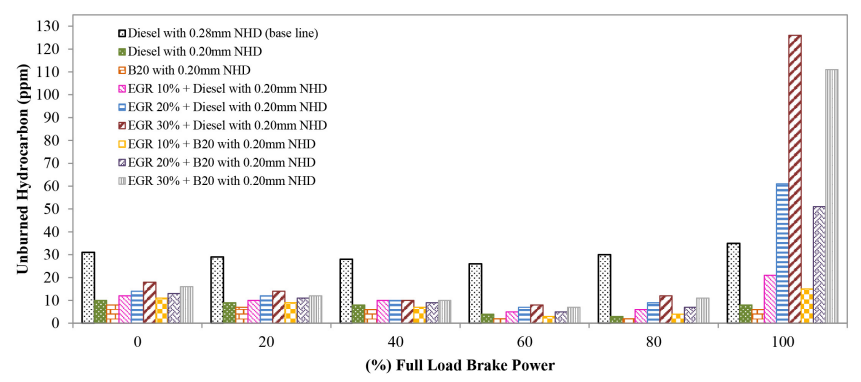

Fig.9. Variations of unburned HC at different percentages of full load BP for different combinations of nozzle orifice diameter, fuel type, and EGR rate.

\subsubsection{Oxides of nitrogen}

The variations of $\mathrm{NO}_{\mathrm{x}}$ at different percentages of full load $\mathrm{BP}$ for different combinations of nozzle orifice diameter, fuel type, and EGR rate are shown in Figure 10. $\mathrm{NO}_{\mathrm{x}}$ is generally formed when $\mathrm{N}_{2}$ and $\mathrm{O}_{2}$ react at high temperatures in the combustion process. The $\mathrm{NO}_{\mathrm{x}}$ emissions measured for the modified orifice diameter stood higher. Using the biodiesel blend, $\mathrm{NO}_{\mathrm{x}}$ must have been formed mainly in the premixed combustion and in the outer layers of the diffusion flame, where the temperature is high and there is a lot of $\mathrm{O}_{2}$ presents (i.e., the $\mathrm{O}_{2}$ contained in the B20). As shown in Figure 10, the application of the EGR substantially reduced the $\mathrm{NO}_{\mathrm{x}}$ emissions. This was in line with the findings of the previous studies indicating that increasing EGR rates led to reduced $\mathrm{NO}_{\mathrm{x}}$ formation (Sasaki et al., 1998; Mani et al., 2010). These results could be ascribed to the effect of EGE in decreasing $\mathrm{O}_{2}$ concentration and flame temperature in the combustible mixture. This was also in line with the results obtained on in-cylinder temperature (Figure 10) implying reduced tepmretures in response to increasing EGR rates.

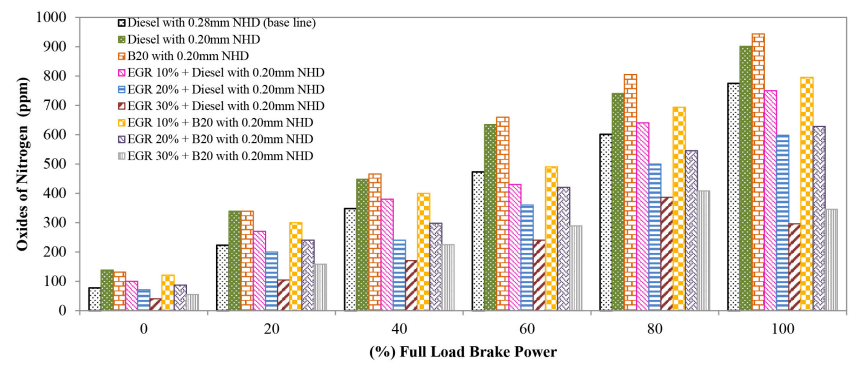

Fig.10. Variations of NOx at different percentages of full load BP for different combinations of nozzle orifice diameter, fuel type, and EGR rate.

\subsubsection{Smoke opacity}

The variations in smoke opacity at different percentages of full load BP for different combinations of nozzle orifice diameter, fuel type, and EGR rate are shown in Figure 11. Smoke opacity is measured to quantify the amount of particulate matter (PM) present in the exhaust gas. The modified orifice diameter reduced smoke opacity when combusting both diesel and B20. As the flow rate of EGR into the combustion chamber was increased, smoke opacity also increased. Comparing diesel and B20 at different EGR 
rates, the latter led to more favorable results on smoke opacity because of the $\mathrm{O}_{2}$ concentration present in biodiesel (Fig. 11). In another words, EGR reduced the availability of $\mathrm{O}_{2}$ for the combustion of fuel, which in turn resulted in relatively incomplete combustion and increased formation of PM. The lower in-cylinder temperatures in response to the increasing EGR rates must have also contributed to the increases observed in smoke opacity (Rajan and Senthilkumar, 2009).

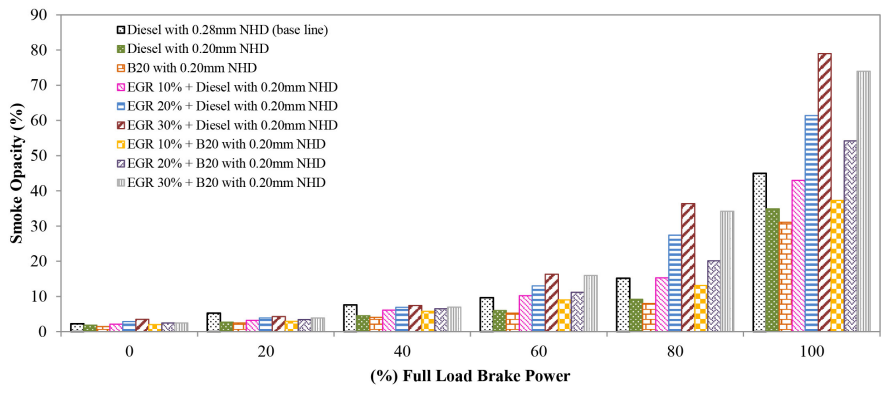

Fig.11. Variations in smoke opacity at different percentages of full load BP for different combinations of nozzle orifice diameter, fuel type, and EGR rate.

\section{Conclusions}

Experiments were conducted with neat diesel and $20 \%$ blend of Mahua oil biodiesel with base and modified NHD while different EGR rates (i.e., 10\%, $20 \%$, and $30 \%$ ) were also employed to overcome the challenges faced regarding $\mathrm{NO}_{\mathrm{x}}$ emissions. Combustion characteristics of different combinations of nozzle orifice diameter, fuel type, and EGR rate were recorded and the obtained data were compared with baseline data on neat diesel. Accordingly, the following main conclusions could be drawn

- The smaller orifice NHD of $0.20 \mathrm{~mm}$ was substantially beneficial in improving the engine performance parameters, i.e., BTE, BSFC, P- $-\theta$, and $\mathrm{HRR}$ as well as in reducing the emissions associated with both diesel and B20. However, the modification implemented led to increased $\mathrm{NO}_{\mathrm{x}}$ which was is a major drawback. These results were mainly attributed to the more efficient atomization and proper mixing of air-fuel mixtures in response to smaller orifice NHD.

Partially-cooled EGR rate of $10 \%$ was found promising for both B20 and diesel when the proposed engine modification (i.e., smaller orifice NHD) was carried out.

- $\quad$ By increasing the EGR, $\mathrm{NO}_{\mathrm{x}}$ emissions were drastically decreased at all the applied load conditions. This could be explained by the reduced $\mathrm{O}_{2}$ concentration and reduced flame temperatures in the combustible mixture as a result of EGR implementation.

- Beyond the EGR rate of $10 \%$, the performance, combustion, and emissions characteristics deteriorated mainly due to the recirculation of high amounts of unburnt soot, $\mathrm{CO}_{2}, \mathrm{H}_{2} \mathrm{O}$, as well as of $\mathrm{O}_{2}$ deficiency.

The application of high EGR rates led to increased soot formation by decreasing the availability of $\mathrm{O}_{2}$ for fuel combustion and the consequent relatively incomplete combustion.

Overall and based on the findings of the present study, engine modification, i.e., shifting from the base orifice NHD of $0.28 \mathrm{~mm}$ to the modified value of $0.20 \mathrm{~mm}$ in the presence of partially-cooled EGR rate of $10 \%$ could be recommended as efficient combustion conditions for $20 \%$ blend of Mahua oil biodiesel and diesel.

\section{Acknowledgements}

The authors are very grateful to the Founding Chairman of the Malla Reddy Engineering College (Dhulapally, Secunderabad) and the Director of the National Institute of Technology Warangal for their support in the conducting of the present study.

\section{References}

[1] Achten, W.M.J., Verchot, L., Franken, Y.J., Mathijs, E., Singh, V.P., Aerts, R., Muys, B., 2008. Jatropha bio-diesel production and use. Biomass Bioenergy. 32(12), 1063-1084.

[2] Agarwal, A.K., Dhar, A., 2013. Experimental investigations of performance, emission and combustion characteristics of Karanja oil blends fuelled DICI engine. Renew. Energy. 52, 283-291.

[3] Atabani, A.E., Silitonga, A.S., Ong, H.C., Mahlia, T.M.I., Masjuki, H.H., Badruddin, I.A., Fayaz, H., 2013. Non-edible vegetable oils: a critical evaluation of oil extraction, fatty acid compositions, biodiesel production, characteristics, engine performance and emissions production. Renew. Sust. Energy Rev. 18, 211-245.

[4] Azam, M.M., Waris, A., Nahar, N.M., 2005. Prospects and potentia of fatty acid methyl esters of some non-traditional seed oils for use as biodiesel in India. Biomass Bioenergy. 29(4), 293-302.

[5] Bai, Y.L., Wang, Z., Wang, J.X., 2010. Part load characteristics of direct injection spark ignition engine using exhaust gas trap. Appl. Energy. 87(8), 2640-2646.

[6] Can, Ö., Öztürk, E., Solmaz, H., Aksoy, F., Çinar, C., Yücesu, H.S., 2016. Combined effects of soybean biodiesel fuel addition and EGR application on the combustion and exhaust emissions in a diesel engine. Appl. Therm. Eng. 95, 115-124.

[7] Channapattana, S.V., Pawar, A.A., Kamble, P.G., 2015. Effect of injection pressure on the performance and emission characteristics of VCR engine using Honne biodiesel as a fuel. Mater. Today Proc. 2(4-5), 1316-1325.

[8] Chauhan, B.S., Kumar, N., Cho, H.M., 2012. A study on the performance and emission of a diesel engine fueled with Jatropha biodiesel oil and its blends. Energy. 37(1), 616-622.

[9] Chauhan, B.S., Kumar, N., Cho, H.M., Lim, H.C., 2013. A study on the performance and emission of a diesel engine fueled with Karanja biodiesel and its blends. Energy. 56, 1-7.

[10] Dubey, P., Gupta, R., 2018. Influences of dual bio-fuel (Jatropha biodiesel and turpentine oil) on single cylinder variable compression ratio diesel engine. Renew. Energy. 115, 1294-1302.

[11] Duraisamy, M.K., Balusamy, T., Senthilkumar, T., 2011. Reduction of NOx emission in Jatropha seed oil fueled CI engine. ARPN J. Eng. Appl. Sci. 6(5), 34-39.

[12] Fontana, G., Galloni, E., 2010. Experimental analysis of a sparkignition engine using exhaust gas recycle at WOT operation. Appl. Energy. 87(7), 2187-2193.

[13] Ganapathy, T., Gakkhar, R.P., Murugesan, K., 2011. Influence of injection timing on performance, combustion and emission characteristics of Jatropha biodiesel engine. Appl. Energy. 88(12), 4376-4386

[14] Gnanasekaran, S., Saravanan, N., Ilangkumaran, M., 2016. Influence of injection timing on performance, emission and combustion characteristics of a DI diesel engine running on fish oil biodiesel. Energy. 116, 1218-1229

[15] Godiganur, S., Murthy, C.S., Reddy, R.P., 2009. 6BTA 5.9 G2-1 Cummins engine performance and emission tests using methyl ester mahua (Madhuca indica) oil/diesel blends. Renew. Energy. 34(10), 2172-2177

[16] Gui, M.M., Lee, K.T., Bhatia, S., 2008. Feasibility of edible oil vs. non-edible oil vs. waste edible oil as biodiesel feedstock. Energy. 33(11), 1646-1653

[17] Gumus, M., Sayin, C., Canakci, M., 2012. The impact of fuel injection pressure on the exhaust emissions of a direct injection diesel engine fueled with biodiesel-diesel fuel blends. Fuel. 95, 486494

[18] Herbinet, O., Pitz, W.J., Westbrook, C.K., 2008. Westbrook. Detailed chemical kinetic oxidation mechanism for a biodiesel surrogate. Combust. Flame. 154(3), 507-528.

[19] Hussain, J., Palaniradja, K., Alagumurthi, N., Manimaran, R., 2012. Petracted: effects of exhaust gas recirculation (EGR) on performance and emission characteristics of a three cylinder direct injection compression ignition engine. Alexandria Eng. J. 51(4), 241-247.

[20] Hussain, J., Palaniradja, K., Alagumurthi, N., Manimaran, R., 2012. Retracted: effect of exhaust gas recirculation (EGR) on

Please cite this article as: Vijay Kumar M., Veeresh Babu A., Ravi Kumar P., Sudhakara Reddy S. Experimental investigation on the diesel and MME blend with DI diesel engine modified with EGR and nozzle hole orifice diameter. Biofuel Research Journal 19 (2018) 863-871. DOI: 10.18331/BRJ2018.5.3.6 
performance and emission characteristics of a three cylinder direct injection compression ignition engine. Alexandria Eng. J. 51(4), 241247.

[21] Jena, P.C., Raheman, H., Kumar, G.P., Machavaram, R., 2010. Biodiesel production from mixture of mahua and simarouba oils with high free fatty acids. Biomass Bioenergy. 34(8), 1108-1116.

[22] Jindal, S., Nandwana, B.P., Rathore, N.S., Vashistha, V., 2010. Experimental investigation of the effect of compression ratio and injection pressure in a direct injection diesel engine running on Jatropha methyl ester. Appl. Therm. Eng. 30(5), 442-448.

[23] Karmee, S.K., Chadha, A., 2005. Preparation of biodiesel from crude oil of Pongamia pinnata. Bioresour. Technol. 96(13), 1425-1429.

[24] Koh, M.Y., Ghazi, T.I.M., 2011. A review of biodiesel production from Jatropha curcas L. oil. Renew. Sust. Energy Rev. 15(5), 2240-2251.

[25] Koutroubas, S.D., Papakosta, D.K., Doitsinis, A., 1999. Adaptationandyieldingabilityof castor plant (Ricinuscommunis L.) genotypes in a Mediterranean climate. Eur. J. Agron. 11(3-4), 227237.

[26] Kumar, A., Sharma, S., 2011. Potential non-edible oil resources as biodiesel feedstock: an Indian perspective. Renew. Sust. Energy Rev. 15(4), 1791-1800.

[27] Kusaka, J., Okamoto, T., Daisho, Y., Kihara, R., Saito, T., 2000. Combustion and exhaust gas emission characteristics of a diesel engine dual-fueled with natural gas. JSAE Rev. 21(4), 489-496.

[28] Lai, J.Y., Lin, K.C., Violi, A., 2011. Biodiesel combustion: advances in chemical kinetic modeling. Prog. Energy Combust. Sci. 37(1), 1-14.

[29] Liaquat, A.M., Masjuki, H.H., Kalam, M.A., Varman, M., Hazrat, M.A., Shahabuddin, M., Mofijur, M., 2012. Application of blend fuels in a diesel engine. Energy Procedia. 14, 1124-1133.

[30] Mani, M., Nagarajan, G., Sampath, S., 2010. An experimental investigation on a DI diesel engine using waste plastic oil with exhaust gas recirculation. Fuel. 89(8), 1826-1832.

[31] Mofijur, M., Masjuki, H.H., Kalam, M.A., Atabani, A.E., 2013. Evaluation of biodiesel blending, engine performance and emissions characteristics of Jatropha curcas methyl ester: Malaysian perspective. Energy. 55, 879-887.

[32] Mo, J., Tang, C., Li, J., Guan, L., Huang, Z., 2016. Experimental investigation on the effect of $n$-butanol blending on spray characteristics of soybean biodiesel in a common-rail fuel injection system. Fuel. 182, 391-401.

[33] Nabi, M.N., Akhter, M.S., Shahadat, M.M.Z., 2006. Improvement of engine emissions with conventional diesel fuel and diesel-biodiesel blends. Bioresour. Technol. 97(3), 372-378

[34] Naik, M., Meher, L.C., Naik, S.N., Das, L.M., 2008. Production of biodiesel from high free fatty acid karanja (Pongamia pinnata) oil. Biomass Bioenergy. 32(4), 354-357.

[35] No, S.Y., 2011. Inedible vegetable oils and their derivatives for alternative diesel fuels in CI engines: a review. Renew. Sust. Energy Rev.15(1), 131-49.

[36] Pinzi, S., Garcia, I.L., Lopez-Gimenez, F.J., Luque de Castro, M.D., Dorado, G., Dorado, M.P., 2009. The ideal vegetable oil-based biodiesel composition: a review of social, economical and technical implications. Energy Fuels. 23(5), 2325-2341.

[37] Raheman, H., Ghadge, S.V., 2007. Performance of compression ignition engine with mahua (Madhuca indica) biodiesel. Fuel. 86(16), 25682573.

[38] Raheman, H., Phadatare, A.G., 2004. Diesel engine emissions and performance from blends of karanja methyl ester and diesel. Biomass Bioenergy. 27(4), 393-397.

[39] Rahman, S.A., Masjuki, H.H., Kalam, M.A., Abedin, M.J., Sanjid, A., Rahman, M.M., 2014. Assessing idling effects on a compression ignition engine fueled with Jatropha and Palm biodiesel blends. Renew. Energy. 68, 644-650.

[40] Rahman, S.A., Masjuki, H.H., Kalam, M.A., Abedin, M.J., Sanjid, A., Imtenan, S., 2014. Effect of idling on fuel consumption and emissions of a diesel engine fueled by Jatropha biodiesel blends. J. Cleaner Prod. 69, 208-215

[41] Rajan, K., Senthilkumar, K.R., 2009. Effect of EGR on performance and emission characteristics of diesel engine with sunflower oil methyl ester. Jordan J. Mech. Ind. Eng. 3(4), 306-311.
[42] Ramadan, M.F., Moersel, J.T., 2003. Phospholipid composition of niger (Guizotia abyssinica cass.) seedoil. LWT-Food Sci. Technol. 36(2), 273-276

[43] Ramadhas, A.S., Jayaraj, S., Muraleedharan, C., 2005a. Biodiesel production from high FFA rubber seed oil. Fuel. 84(4), 335-340.

[44] Ramadhas, A.S., Jayaraj, S., Muraleedharan, C., 2005b. Characterization and effect of using rubber seed oil as fuel in the compression ignition engines. Renew. Energy. 30(5), 795-803.

[45] Sahoo, P.K., Das, L.M., Babu, M.K.G., Naik, S.N., 2007. Biodiese development from high acid value polanga seed oil and performance evaluation in a CI engine. Fuel. 86(3), 448-454.

[46] Saka, S., 2005. Production of biodiesel: current and future technology. In JSPS/VCO Core University program seminar, Universiti Sains Malaysia. 62-102.

[47] Sasaki, S., Sawada, D., Ueda, T., Sami, H., 1998. Effect of EGR on direct injection gasoline engine. JSAE Rev. 19(3), 223-228.

[48] Sharma, V., Das, L., Pradhan, R.C., Naik, S.N., Bhatnagar, N., Kureel, R.S., 2011. Physical properties of tung seed: an industrial oil yielding crop. Ind. Crops Prod. 33(2), 440-444

[49] Shehata, M.S., Attia, A.M., Razek, S.A., 2015. Corn and soybean biodiesel blends as alternative fuels for diesel engine at different injection pressures. Fuel. 161, 49-58.

[50] Silitonga, A.S., Atabani, A.E., Mahlia, T.M.I., Masjuki, H.H., Badruddin, I.A., Mekhilef, S., 2011. A review on prospect of Jatropha curcas for biodiesel in Indonesia. Renew. Sust. Energy Rev. 15(8), 3733-3756.

[51] Singh, S.P., Singh, D., 2010. Biodiesel production through the use of different sources and characterization of oils and their esters as the substitute of diesel: a review. Renew. Sust. Energy Rev. 14(1), 200216

[52] Sivaramakrishnan, K., 2018. Investigation on performance and emission characteristics of a variable compression multi fuel engine fuelled with Karanja biodieselediesel blend. Egypt. J. Pet. 27(2), 177-186.

[53] Sureshkumar, K., Velraj, R., Ganesan, R., 2008. Performance and exhaust emission characteristics of a CI engine fueled with Pongamia pinnata methyl ester (PPME) and its blends with diesel. Renew. Energy. 33(10), 2294-2302.

[54] Venkanna, B.K., Reddy, C.V., 2009. Biodiesel production and optimization from Calophyllum inophyllum linn oil (honne oil)-A three stage method. Bioresour. Technol. 100(21), 5122-5125.

[55] Vijay Kumar, M., Veeresh Babu, A., Ravi Kumar, P., 2017a. Producing biodiesel from crude Mahua oil by two steps of transesterification process. Aust. J. Mech. Eng. 1-6.

[56] Vijay Kumar, M., Veeresh Babu, A., Ravi Kumar, P., 2017b. Experimental investigation on Mahua methyl ester blended with diesel fuel in a compression ignition diesel engine. Int. J. Ambient Energy. 1-13.

[57] Vijay Kumar, M., Veeresh Babu, A., Ravi Kumar, P., 2018a. The impacts on combustion, performance and emissions of biodiesel by using additives in direct injection diesel engine. Alexandria Eng. J. 57(1), 509-516.

[58] Vijay Kumar, M., Veeresh Babu, A., Ravi Kumar, P., 2018b Experimental investigation on the effects of diesel and Mahua biodiesel blended fuel in direct injection diesel engine modified by nozzle orifice diameters. Renew. Energy. 119, 388-399.

[59] Vijayaraj, K., Sathiyagnanam, A.P., 2016. Experimental investigation of a diesel engine with methyl ester of mango seed oil and diesel blends. Alexandria Eng. J. 55(1), 215-221. 